\title{
PENGARUH PEMBERDAYAAN DAN PEMBINAAN TERKEMUKA TERHADAP KERJA KARYAWAN DI SATUAN SABHARA POLRES BATU
}

\author{
*Heylen Amildha Yanuarita ${ }^{1)}$, Hariyanto ${ }^{2)}$ \\ 1) Program Studi Administrasi Publik Universitas Kadiri, Indonesia \\ 2) Program Studi Administrasi Publik Universitas Kadiri, Indonesia \\ 3) Program Studi Administrasi Publik Universitas Kadiri, Indonesia \\ *Email Korespondensi : heylenay@unik-kediri.ac.id
}

\begin{abstract}
Abstrak
Kinerja polisi yang profesional, modern, bermoral dan patuh hukum merupakan aspek yang dapat ditingkatkan melalui faktor-faktor pengembangan kepemimpinan yakni, pembinaan, pelatihan dan pengembangan,pemberdayaan dan partisipasi. Untuk itu POLRI harus dapat menerapkan faktorfaktor pengembangan kepemimpinan diatas dalam rangka meningkatkan kinerja polisi yang profesional, modern, bermoral dan patuh hukum.Tujuan dari penelitian ini adalah: untuk mengetahui dan menganalisis pengaruh pembinaan dan pemberdayaan pimpinan terhadap kinerja bawahan di Satuan Sabhara Polres Batu. Tipe penelitian ini merupakan penelitian deskriptif dengan pendekatan penelitian kualitatif. Informan yang akan peneliti wawancarai adalah pihakpihak yang terlibat dalam pembinaan, pemberdayaan pimpinan dan kinerja bawahan di Satuan Sabhara Polres Batu. Hasil penelitian menunjukkan bahwa Pembinaan dan pemberdayaan pimpinan sangat berpengaruh terhadap kinerja bawahan di satuan Sabhara Polres Batu hal ini terlihat Pelaksanaan tugas Satuan Sabhara Polresta Batu sebagian besar telah terlaksana dengan baik, dan telah berupaya meningkatkan pelaksanaan tugas fungsi Sabhara yang berwibawa di tengah-tengah masyarakat untuk menciptakan situasi kamtibmas yang mantap dan terkendali dikarenakan adanya program pembinaan dan pemberdayaan pimpinan dilaksanakan secara baik, rutin dan terus menerus.
\end{abstract}

Kata Kunci: Pembinaan; Pemberdayaan; Kinerja

\begin{abstract}
Police performance that is professional, modern, moral and law-abiding is an aspect that can be improved through leadership development factors, namely, coaching, training and development, empowerment and participation. For this reason, the Indonesian National Police must be able to apply the leadership development factors above in order to improve the performance of the police that are professional, modern, moral and law-abiding. The purpose of this research is: to find out and analyze the influence of leadership coaching and empowerment on the performance of subordinates in the Batu Sabara Police Unit. This type of research is a descriptive study with a qualitative research approach. The informants who will be interviewed by the researchers are those who are involved in guiding, empowering the leadership and the performance of subordinates in the Sabhara Unit of the Batu Police Resort. The results showed that the Guidance and empowerment of leaders greatly affected the performance of subordinates in the BatuSabhara
\end{abstract}


Police Unit. Create a steady and controlled kamtibmas situation due to a coaching program and leadership empowerment carried out properly, routinely and continuously.

Keywords: Coaching; Empowerment; Performance

\section{PENDAHULUAN}

Kepolisian Republik Indonesia (POLRI) memegang peranan yang memiliki fungsi, tugas pokok dan wewenang melaksanakan sebagian urusan pemerintahan di bidang: (a) pemeliharaan keamanan dan ketertiban masyarakat; (b) penegakan hukum; (c) perlindungan, pengayoman, dan pelayanan kepada masyarakat. Terlebih dalam era reformasi ini, masyarakat menuntut pemerintahan yang demokratis dengan terwujudnya supremasi sipil yaitu aparatur pemerintahan berada di atas kepentingan rakyat. Oleh sebab itu, dalam mengawal kehidupan masyarakat ke arah kehidupan demokratis maka dituntut profil polisi yang profesional, yang mampu menjalankan fungsi dan tugas pokoknya dalam memberikan pelayanan keamanan yang bertujuan melindungi harkat dan martabat manusia sehingga dapat menjalankan produktifitasnya dengan aman.

POLRI sebagai sub sistem dari pemerintah secara responsif telah berupaya memberi kontribusi mewujudkan prinsip Good Governance dan Clean Government baik dalam pelaksanaan tugas pokok memelihara Kamtibmas, menegakkan hukum dan melindungi, mengayomi serta melayani masyarakat maupun di kalangan internal Polri sendiri sebagaimana dicanangkan dalam grand strategi POLRI berupa Strive for Excellence. Strive for Excellence (2016 - 2025) merupakan grand strategi POLRI tahap ketiga yakni untuk membangun kemampuan pelayanan publik yang unggul, mewujudkan Good government, best practice POLRI, dan profesionalisme sumber daya manusia.

Profesionalisme merupakan tuntutan yang tidak bisa dihindari jika menginginkan kinerja yang baik (Nurohman, n.d.). Selain itu juga tidak boleh mengesampingkan aspek moralitas personel dalam melaksanakan tugas. Kondisi riil untuk menilai keberhasilan POLRI dalam melaksanakan tugas pokok tersebut antara lain ditentukan oleh kualitas moral dan profesionalisme serta persepsi masyarakat terhadap kinerja POLRI. Profesionalisme dan moralitas yang baik dalam pelayanan masyarakat akan menghasilkan kinerja yang baik dan tentunya bersih dari KKN. 
Salah satu misi POLRI adalah mengelola sumber daya manusia POLRI secara profesional dalam mencapai tujuannya yaitu terwujudnya keamanan dalam negeri, sehingga dapat mendorong meningkatnya gairah kerja guna mencapai kesejahteraan masyarakat. Misi ini menjadi dasar dari upaya pembinaan sumber daya manusia. Dengan adanya misi yang menyentuh aspek sumber daya manusia, maka sesungguhnya POLRI telah berupaya untuk berkomitmen terhadap kualitas kompetensi yang baik bagi para anggotanya (Savitri, 2018). Pengembangan kemampuan, kekuatan, dan penggunaan kekuatan POLRI dikelola sedemikian rupa agar dapat mendukung pelaksanaan tugas POLRI sebagai pengemban fungsi keamanan dalam negeri memiliki peran penting sebagai dasar atas keberhasilan POLRI dalam melaksanakan fungsi dan perannya sebagaimana diamanatkan dalam UU No.2 tahun 2002 tentang Kepolisian RI. Terwujudnya perubahan aspek kultural dimulai dari bagaimana POLRI itu sendiri membangun sistem sumbner daya manusia secara terpadu dan berkesinambungan, serta bukan hanya menuntut aparatur pelaksananya bekerja secara profesional namun para penentu strategi kebijakan sumber daya manusia POLRI pun harus bertindak di atas dasar profesionalisme yang objektif mengesampingkan hal-hal yang bersifat subjektif. Jika POLRI mampu melaksanakan manajemen sumber daya manusia dengan baik, diharapkan perubahan kultur menuju polisi yang profesional, modern, bermoral dan patuh hukum sebagai perwujudan polisi sipil dalam masyarakat yang demokratis dapat terwujud.

Kinerja polisi yang profesional, modern, bermoral dan patuh hukum merupakan aspek yang dapat ditingkatkan melalui faktor-faktor pengembangan kepemimpinan yakni, pembinaan, pelatihan dan pengembangan, pemberdayaan dan partisipasi. Untuk itu POLRI harus dapat menerapkan faktor-faktor pengembangan kepemimpinan diatas dalam rangka meningkatkan kinerja polisi yang profesional, modern, bermoral dan patuh hukum.

Pemahaman itu mengindikasikan bahwa, pengembangan kapasitas kemampuan anggota Kepolisian merupakan persoalan internal menyangkut kapasitas kemampuan pada tingkatan individu, tingkatan organisasi, dan tingkatan sistem yang berkesinambungam.Pada tingkatan individu, pengembangan kapasitas kemampuan menyangkut peningkatan pengetahuan keterampilan kemampuan pengelompokan.Pada tingkatan organisasi, pengembangan kapasitas kemampuan menyangkut kerangka kerja 
format yang mendukung kebijakan - kebijakan pengembangan.Sedang pada tingkatan sistem, pengembangan kapasitas kemampuan menyangkut kerangka pengambilan keputusan sumber - sumber prosedur institusi. Agar POLRI dapat menjalankan tugas pokok dan fungsinya secara professional, perlu terus secara berkala dilakukan pembinaan dan kepelatihan dibidangnya sesuai dengan golongan, pangkat dan jabatannya.

\section{TINJAUAN PUSTAKA}

Menurut peneliti (Thoha, 2017), pada dasarnya seorang pegawai dalam menjalankan tugas yang dibebankan kepadanya diharapkan untuk menunjukan suatu performance yang terbaik yang bisa ditunjukkan oleh pegawai tersebut. Selain itu performance yang ditunjukkan oleh seorang pegawai tentu saja dipengaruhi oleh berbagai faktor yang penting artinya bagi peningkatan hasil kerja yang menjadi tujuan dari organisasi atau intansi dimana pegawai tersebut bekerja.

Performance atau kinerja ini perlu senantiasa diukur oleh pimpinan agar dapat diketahui sampai sejauh mana perkembangan kinerja dari seorang pegawai pada khususnya dan pada organisasi pada umumnya. Menurut Mahsun (Machmud, 2014), kinerja (performance) adalah gambaran mengenai tingkatan pencapaian pelaksanaan suatu kegiatan / program / kebijakan dalam mewujudkan sasaran, tujuan, misi, dan visi organisasi yang tertuang dalam strategic planning suatu organisasi. Sedangkan kinerja menurut LA.N dalam Sedarmayanti, mengatakan bahwa performance diterjemahkan menjadi kinerja, juga berarti prestasi kerja, pelaksanaan kerja, pencapaian kerja atau hasil kerja atau untuk kerja atau penampilan kerja (Rosita \& Yuniati, 2016). Dalam rangka program pembinaan kepada karyawan, maka perlu diketahui kinerja pegawai meningkat atau menurun. Jika meningkat perlu mendapat reward namun jika ternyata kinerja menurun perlu pula memperoleh peringatan atau kalau perlu sanksi. Jika demikian perlu dilakukan pengukuran kinerja.

Dalam rangka keperluan evaluasi kinerja, tentunya ada faktor-faktor kinerja. Berikut faktor-faktor kinerja sebagai indikator untuk diukur atau dievaluasi, antara lain (Anggreny, 2018) : faktor personal/individual, kepemimpinan, faktor tim, faktor sistem, meliputi: sistem kerja, fasilitas kerja atau insfrastruktur yang diberikan oleh organisasi, 
proses organisasi, dan kultur kinerja dalam organisasi dan kontekstual. Sementara itu pengukuran kinerja Keith Davis dalam Mangkunegara menjelaskan bahwa ada dua unsur pengukuran kinerja, yaitu unsur kemampuan (ability) dan unsur motivasi yang diterjemahkan sebagai attitude pimpinan dalam melaksanakan tiugas sehari-hari (Sudiyatno \& Puspitasari, 2010). Sedikit berbeda dengan Simamora, Pendapat Simamora, kinerja pegawai dapat dilihat dari sudut keputusan tentang aturan organisasi, pelaksanaan tugas dengan minimal kealahan, ketepatan dalam menjalankan tugas.

Banyak faktor yang mempengaruhi kinerja, salah satunya adalah faktor pembinaan. Hal ini sesuai dengan pernyataan Ivancevich, bahwa pembinaan sebagai usaha untuk meningkatkan kinerja pegawai dalam pekerjaannya sekarang atau dalam pekerjaan lain yang akan dijabatnya segera (Siswahyudi, 2018). Berbeda pula dengan Mathhis, menyebutkan bahwa pembinaan merupakan proses pencapaian kemampuan tertentu sebagai upaya mencapai organisasi. Dalam hal pembinaan tentunya terkait erat dengan pencapaian tujuan organisasi (Ardiana et al., 2010).

Pembinaan berorientasi ke masa sekarang dan membantu pegawai untuk menguasai keterampilan dan kemampuan (kompetensi) yang spesifik untuk berhasil dalam pekerjaannya. Mathis juga mengemukakan empat tingkatan pokok dalam kerangka kerja untuk mengembangkan rencana pembinaan strategis, antara lain pengaturan strategi, perencanakan, pengorganisasian, monetering dan evaluasi.

Pembinaan dapat diartikan melakukan pembaharuan artinya mengubah sesuatu menjadi lebih mengandung nilai-nilai pembaharuan dan lebih berguna untuk kehidupan yang akan datang. Adapun pembinaan dapat pula diartikan sebagai bentuk pengawasan karena merupakan usaha untuk membuat sesuatu lebih sesuai dengan kebutuhan yang telah direncanakan. Berbeda pula dengan pernyataan Tangdilintin mengatakan pembinaan akan menjadi suatu "empowerment" atau pemberdayaan karena mengandung maksud penyadaran, meningkatkan kepercayaan diri, menumbuhkan kesadaran kritis, konstruksi dan bertanggung jawab, dan mendorong berperan sosial aktif. Pola pembinaan merupakan kegiatan-kegiatan individu yang secara langsung terlibat dalam persiapan dan penentuan kegiatan-kegiatan tersebut. Pola pembinaan adalah tingkah laku seseorang dalam 
organisasi yang bermaksud merubah keadaan psikis atau pisik penerima sedemikian rupa (yang lebih baik), sehingga dapat dicapai tujuan organisasi.

Adapun lingkup pembinaan meliputi controlling dan supervisi, mengingat keduanya merupakan bagian dari pembinaan sebagai fungsi dari manajemen (Kusumawati \& Maruti, 2019). Pengawasan dilaksanakan berdasarkan prinsip otokrasi, dan supervisi merupakan fungsi untuk membina situasi penyelenggaraan kegiatan melalui upaya pelayanan, bantuan, dan bimbingan ke arah perbaikan situasi secara menyeluruh. Kaitanya dengan pimpinan dalam rangka kelancaran tugas yaitu membina hubungan baik, melalui pendekatan menumbuhkan motivasi diri yang timbul dan melekat pada diri pegawai itu sendiri. Disamping juga mengadakan kompetisi yang sehat untuk meningkatkan produktifitas kerja, serta menimbulkan konflik yang sifatnya positif dengan maksud dapat mengubah tingkah laku pegawai. Kaitan lain yaitu membagi tanggung jawab sesuai dengan kemampuan pegawai untuk membuat suatu keputusan yang ada hubungannya dengan tugas-tugasnya. Hal tersebut dilakukan untuk dapat mencapai sasaran organisasi dan perorangan dengan setiap pegawai berkontribusi atas dasar hasrat dan kemampuannya, koordinasi dan menggerakkan aktivitas, penerapan kerjasama dan loyalitas, mengusahakan iklim persaudaraan, kesetiakawanan dan melaksanakan kebijaksanaan pimpinannya dengan baik. Adapun pelaksanaan pembinaan dengan pendekatan langsung, tidak langsung maupun campuran. Terdapat beberapa macam pembinaan, antara lain pembinaan karir, pembinaan disiplin, pembinaan pendidikan dan pelatihan.

Pemberdayaan diartikan lebih berdaya dari sebelumnya, baik dalam hal wewenang tanggung jawab maupun kemampuan individual yang dimilikinya (Putri, 2016). Pemahaman pemberdayaan secara lugas sebagai proses pemberian daya atau kekuatan atau kemampuan (Hadi, 2010). Pemberdayaan tidak hanya sekedar memiliki masukan tetapi juga memperhatikan, mempertimbangkan dan menindak lanjuti masukan tersebut apakah diterima atau tidak. Tanpa adanya pemberdayaan, perlibatan karyawan hanyalah merupakan alat manajemen yang tidak ada gunanya.

Dalam konsep pemberdayaan menampakkan dua kecendrungan, yang menekankan kepada proses pemberian atau pengalihan sebagian kekuasaan, kekuatan, 
atau kemampuan kepada masyarakat, organisasi, atau individu agar menjadi lebih berdaya (Hadi, 2010). Proses ini sering disebut sebagai kecendrungan primer dari makna pemberdayaan. Bisa juga sebagai proses menstimulasi, mendorong, dan memotivasi individu agar mempunyai kemampuan atau keberdayaan untuk menentukan apa yang menjadi pilihan hidupnya. Proses ini sering disebut sebagai kecenderungan sekunder dari makna pemberdayaan.

Sebagai proses, pemberdayaan merupakan serangkaian kegiatan yang dilakukan untuk meningkatkan atau memperbaiki kemampuan dari status kurang berdaya menjadi berdaya. Sebagai tujuan, pemberdayaan menunjuk kepada keadaan atau hasil yang ingin dicapai oleh sebuah perubahan sosial sehingga kinerja dapat meningkat, mulai dari tingkat pimpinan tertinggi sampai kepada tingkat bawahan operasional dalam organisasi lebih bertanggung jawab. Komponen utama pemberdayaan yang dimaksud adalah anggota aparatur. Selanjutnya untuk mengetahui penerapannya apakahpelaksanaan pemberdayaan telah dilaksanakan dengan baik, maka dapat ditinjau dengan melihat kepada proses-proses pemberdayaan. Pelaksanaan proses pemberdayaan setahap demi setahap, antara lain :

1. Tahap Persiapan, yaitu tahap penyiapan petugas (community worker).

2. Tahap Pengkajian (assesment)

3. Tahap Perencanaan Alternatif

4. Tahap capacity building dan networking : melakukan penelitian, workshop, masyarakat, membangun jaringan dengan pihak luar,

5. Tahap pelaksanaan dan pendampingan

6. Tahap Evaluasi : memantau, mengevaluasi danmencari solusi atas konflik

7. Tahap Terminasi, yaitu pemberdayaan sumber daya aparatur yaitu peningkatan efektifitas, menghendaki dilakukannya perubahan administrasi (birokrasi) atau reformasi kinerja aparatur pemerintah. Pemberdayaan aparatur merupakan usaha untuk lebih meningkatkan kemampuan dalam melaksanakan tugas umum, mengemukakan pendapatnya tentang pemberdayaan aparatur sebagai berikut: upaya memberikan otonomi, wewenang dan kepercayaan kepada setiap individu dalam suatu organisasi, serta mendorong mereka untuk kreatif agar dapat merampungkan tugasnya sebaik 
mungkin (Hendayady, 2011). Agar dapat terwujud pemberdayaan yang dimaksud, maka diperlukan perubahan peraturan perundang-undangan yangmengatur mengenai kepegawaian yang meliputi pengadaan, pengembangan,pembinaan, pengkajian dan pengawasan.

\section{METODE PENELITIAN}

Berdasarkan pada permasalahan yang menggunakan kata bagaimana, maka pendekatan penelitin ini adalah pendekatan penelitian deskriptif (Soendari, 2012). Selanjutnya (Gunawan, 2013) menyatakan pendekatan penelitian yang berlandaskan pada fenomenologi dan paradigma konstruktivisme dalam megembangkan ilmu pengetahuan merupakan pendekatan kualitatif. Pengertian lain menurut (Semiawan, 2010) metode penelitian kualitatif adalah suatu prosedur penelitian yang menghasilkan data deskriptif berupa kata-kata tulisan atau lisan dari orang-orang dan perilaku yang dapat diamati. Adapun sumber data utama dalam penelitian kualitatif ialah kata-kata dan tindakan, selebihnya adalah data tambahan seperti dokumen dan lain-lain. Dalam penelitian ini sumber data utama tersebut dicatat melalui catatan tertulis atau perekaman audio atau record voice, dan pengambilan foto. Sedangkan, jenis data yang digunakan yaitu data primer dan data sekunder. Adapun informan adalah orang yang dimanfaatkan untuk memberi informasi tentang suatu situasi dan kondisi latar penelitian (Semiawan, 2010). Teknik penentuan informannya menggunakan pendekatan teknik purposive sampling. Teknik pengumpulan datanya dengan teknik obseervasi, wawancara dan dokumentasi.

Setelah data terkumpul dilakukan uji validasi data dengan teknik validasi sumber. Adapun analisis data merupakan proses pelacakan dan pengaturan secara sistematis transkip-transkip wawancara, catatan lapangan, dan bahan-bahan lain agar penelitidapat menyajikan temuannya. Menurut Bogdan dalam (Sugiono, 2016) analisis data dilakukan dengan mengorganisasikan data, menjabarkannya kedalam unit-unit, meyusun ke dalam pola, memilih mana yang penting dan yang akan dipelajari, dan membuat kesimpulan yang akan di deskripsikan.

\section{HASIL DAN PEMBAHASAN}


Pelaksanaan tugas Satuan Sabhara Polresta Batu berdasarkan pada Rencana Kerja Polresta Batu TA.2019 dengan berpedoman pada Juklak, Juklak dan Juknis Kepolisian serta kebijaksanaan pimpinan Polresta Batu. Kapolres Batu memerintahkan kepada Satuan Sabhara Polres Batu untuk melakukan pembinaan disiplin dan etos kerja serta loyalitas terhadap tugas yang menjadi beban tugasnya sehingga pelaksanaan tugas dapat dilandasi rasa akuntabilitas yang tinggi.

Pembinaan di Satuan Sabhara Polres Batu di program dengan tiga fokus kegiatan yaitu pembinaan rohani, jasmani, keterampilan dan pembinaan mental kepribadian. Pembinaan rohani bertujuan untuk meningkatkan keimanan dan ketaqwaan, sikap mental dan perilaku berlandaskan disiplin, loyalitas, kebanggaan dan kehormatan dengan menerapkan prinsip ganjaran hukuman serta secara periodik memelihara kesabharaan jasmani. Disamping juga meningkatkan moral para personel, seperti dengan menyelenggarakan pelajaran mengenai ESQ (Emotional Spiritual Quotient).

Pembinaan rohani dilakukan 1 minggu sekali setiap hari Kamis dan hari tertentu sesuai dengan kalender kamtibmas tentang hari besar keagamaan. Pelaksanaan ibadah Jum'at di Polres dan umat lain di tempat ibadah masing-masing. Pembinaan jasmani melalui kegiatan latihan pembinaan jasmani yang terprogram guna meningkatkan keprofesionalan anggota di lapangan meliputi olahraga setiap hari sabtu berupa jalan santai , lari dan senam aerobic, juga tes Kesamaptaan Jasmani ( TKJ ) setiap 1 semester / 6 bulan sekali yang meliputi lari, sit up, push up, pull up, shuttle run. Disamping juga melakukan peningkatan ketrampilan dibidang kepolisian melalui pembinaan keterampilan sesuai kewenangan yang dimiliki oleh Satuan Sabhara yang berkaitan dengan upaya peningkatan kekuatan dan kemampuan anggota Satuan Sabhara guna terwujudnya POLRI yang professional dan dicintai masyarakat., misalnya keterampilan menembak (senpi pendek jenis Revolver maupun Senpi panjang jenis SS1V2), keterampilan beladiri polri, tongkat $\mathrm{T}$ dan senam borgol, keterampilan dalmas dan raimas, ketrampilan menggunakan ranmor dinas R2 dan R4, keterampilan SAR terbatas ( pertolongan - penyelaman). Disamping itu juga terus dikembangkan dan ditingkatan berbagai ketrampilan dalam melaksanakan tugasnya antara lain :

a. Keterampilan melumpuhkan serangan dadakan 
b. Keterampilan pemeriksaan dan penggeledahan terhadap tamu yang akan masuk mako polres

c. Keterampilan dalam penyelidikan dan penyidikan tipiring

d. Keterampilan dalam rangka melakukan tindakan pertama di Tempat Kejadian perkara (TKP)

e. Keterampilan pengaturan arus lalu lintas

f. Keterampilan mengawal dan pengamanan tahanan

g. Keterampilan pengawalan dan pengamanan di Obyek Vital

h. Keterampilan ketika menerima tamu

i. Keterampilan melaksanakan pelayanan di Obyek Vital

Pembinaan Mental Kepribadian dilakuakan sebagai mengupayakan kualitas dan professionalisme anggota Satuan Sabhara sebagai penegak hukum, pengayom, pelindung dan pelayan masyarakat yang memiliki mental dan jiwa kejuangan yang tinggi

a. Arahan kapolres setiap hari senin tentang larangan / yang boleh dan tidak boleh dilakukan anggota serta tugas tugas yang akan dilaksanakan pada hari itu dan hari selanjutnya

b. App Kasat Sabhara kepada anggota setiap hari setelah apel pagi terkait evaluasi pelaksanaan tugas serta apa yang seharusnya dilakukan dan apa yang seharusnya tidak boleh dilakukan oleh anggota.

c. Pemberdayaan pimpinan mencakup dua pokok persoalan yang amat penting dalam meningkatkan kinerja organisasi yakni konsep pemberdayaan yang berakar komitmen dan kepercayaan pegawai sebagai suatu strategi dalam menjalankan organisasi.

Upaya dalam menghadapi tantangan seperti inilah diperlukan strategi pemberdayaan pegawai dalam hal ini pemberdayaan struktural, dengan dasar pandangan bahwa upaya yang dilakukan harus menyentuh langsung pada akar persoalannya yaitu meningkatkan kemampuan pembinaan dan produktivitas kerja, yang merupakan bagian tertinggal melalui pengembangan dan mendinamiskan potensinya dengan kata lain pemberdayaan dan pembinaan 
1. Menempatkan anggota di simpul simpul jalan pada jam anak berangkat sekolah / karyawan berangkat kerja guna mengatur arus lalu lintas dan mengurai bilamana ada kemacetan setiap hari.

2. Menempatkan anggota seseuai kegiatan harian Satsabhara Polres Batu, antara lain :

1. Jaga Obyek Vital Bendungan

2. Jaga Perbankan

3. Jaga Mako Polres Batu

4. Jaga wisma Kapolres Batu

5. Pelayanan tempat wisata

6. Patroli Sabhara kendaraan R2 - R4

7. Melaksanakan tindakan Tipiring terhadap pelaku pelanggaran

8. Melaksanakan jaga tahanan

9. Melaksanakan wal tahanan terdakwa korupsi yang akan sidang ke PN Tipikor Surabaya.

Tugas Satuan Sabhara Polresta Batu di rumuskan sesuai dengan tugas pokok Satuan Sabhara hasil analisa pelaksanaan pimpinan dalam rangka membangun Polisi yang lebih baik di masa mendatang serta tindak lanjut di Era Reformasi pada saat ini dan menuju Polisi yang Profesional melalui :

1. Meningkatkan giat rutin Satuan Sabhara dalam bidang (Turjawali) pengaturan, penjagaan, pengawalan dan patroli.

2. Meningkatkan kegiatan preventif dalam rangka mencegah dan menangkal gangguan kamtibmas diwilayah hukum Polresta Batu dengan cara memploting anggota Satuan Sabhara kedaerah-daerah yang dianggap rawan dengan kemacetan arus lalu lintas dan rawan tindak pidana.

3. Meningkatkan kegiatan preventif dalam rangka mencegah terjadinya kejahatan dan pelanggaran baik pelaku perorangan kelompok maupun massa, memberikan bantuan pertolongan dan perlindungan kepada masyarakat serta mengamankan kegiatan masyarakat di wilayah hokum Polresta Batu. 
4. Meningkatkan kegiatan Refresif dalam rangka penegakan hukum melalui kegiatan pemeriksaan terhadap yang keluar masuk Mako baik yang ingin besuk tahanan maupun yang akan melapor.

5. Meningkatkan kegiatan pembinaan kekuatan Personil Sabhara baik dibidang pembinaan sistem, perawatan personil memelihara materil maupun fungsional lainnya guna mendukung tugas-tugas Satuan Sabhara.

6. Memantapkan kualitas pelayanan terhadap masyarakat diwilayah hokum Polresta Batu dalam rangka menumbuh kembangkan kepercayaan masyarakat kepada Polri.

7. Meningkatkan Profesionalisme personil Satuan Sabhara.

Hasil kinerja bawahan di Satuan Sabhara Polres Batu yang dicapai antara lain :

1. Satuan Sabhara ingin mengoptimalkan unjuk kegiatan preventif yang efektif dalam menangani AG dan mencegah GN dengan menetapkan sasaran dan CB yang jelas melalui pengoperasionalan Unit Patroli Satuan Sabhara sejajaran Polresta Batu.

2. Melaksanakan pelaksanaan Patroli rutin R2 dan R4 secara kontinyu serta memonitoring lokasi-lokasi daerah titik rawan, menekan angka kriminalitas, dan Narkoba yang ada diwilayah hukum Polresta Batu.

3. Mengefektifkan pelayanan masyarakat yang datang ke Mako Polresta Batu serta pelayanan yang terbaik untuk masyarakat yang ingin melapor maupun yang ingin membesuk tahanan.

4. Mengkondisikan kesiapan dan kesiap siagaan operasional Kompi Dalmas, didalam mengantisipasi dan penanggulangan unjuk rasa dan kerusuhan massa serta dalam tugas lainnya.

5. Memberikan peningkatan Pelatihan terhadap Personil Satuan Sabhara Polresta melalui pelatihan Formasi-Formasi Dalmas, Beladiri Polri, Dril Borgol / Tongkat Polri serta Perdaspol dan Pemeriksaan Sikap tampang dan gampol anggota untuk kesiapan dilapangan.

Seorang pimpinan pada organisasi POLRI, atau lebih spesifik pimpinan pada tingkat Polres adalah orang yang bekerja dengan bantuan orang lain. Ia tidak menjalankan semua pekerjaan sendiri saja, melainkan mengarahkan orang lain dalam tim untuk 
melaksanakannya. Jika tugas yang diarahkan tidak dapat dilaksanakan oleh anggotanya, seorang pimpinan harus mengetahui sebab-sebabnya. Mungkin anggota yang bersangkutan memang tidak kompeten di bidangnya, tetapi mungkin pula ia tidak mempunyai motivasi untuk bekerja dengan baik. Dengan adanya pemberdayaan pimpinan maka Satuan Sabhara Polres Batu mampu melaksanakan kebijaksanaan pimpinan dibidang pembinaan operasional sesuai kewenangan yang dimiliki oleh Satuan Sabhara yang berkaitan dengan upaya peningkatan kekuatan dan kemampuan anggota Satuan Sabhara guna terwujudnya Polri yang professional dan dicintai masyarakat.

Pelaksanaan tugas Satuan Sabhara Polresta Batu sebagian besar telah terlaksana dengan baik, dan telah berupaya meningkatkan pelaksanaan tugas fungsi Sabhara yang berwibawa di tengah-tengah masyarakat untuk menciptakan situasi kamtibmas yang mantap dan terkendali.Baiknya kinerja bawahan di Satuan Sabhara Polres Batu teraplikasi melalui perbaikan kualitas, kuantitas, ketepatan waktu, orientasi pelayanan, integritas, komitmen, disiplin serta kerjasama hal ini dikarenakan adanya program pembinaan dan pemberdayaan pimpinan dilaksanakan secara baik, rutin dan terus menerus.

Pembinaan dan pemberdayaan pimpinan sangat berpengaruh terhadap kinerja bawahan di satuan Sabhara Polres Batu hal ini karena kinerja polisi yang profesional, modern, bermoral dan patuh hukum merupakan aspek yang dapat ditingkatkan melalui faktor-faktor pengembangan kepemimpinan yakni, pembinaan, pelatihan dan pengembangan, pemberdayaan dan partisipasi. Untuk itu Polri harus dapat menerapkan faktor-faktor pengembangan kepemimpinan diatas dalam rangka meningkatkan kinerja polisi yang profesional, modern, bermoral dan patuh hukum.

Kinerja bawahan di Satuan Sabhara Polres Batu pada segi kualitas teraplikasi melalui kemampuan menyelesaikan tugas dengan teliti serta rapih dan menyelesaikan tugas pekerjaan sesuai dengan Standar Operasional serta Prosedur. Kinerja bawahan di Satuan Sabhara Polres Batu pada segi kuantitas teraplikasi melalui kemampuan menyelesaikan tugas pekerjaan sesuai dengan target yang telah ditentukan dan menyelesaikan pekerjaan tambahan berdasarkan target. Pada segi indikator ketepatan waktu teraplikasi melalui kemampuan menyelesaikan tugas pekerjaan sesuai dengan target waktu yang diberikan oleh pimpinan serta menyelesaikan pekerjaan tambahan 
sesuai dengan target waktu yang berikan oleh pimpinan. Kinerja bawahan di Satuan Sabhara Polres Batu pada segi orientasi pelayanan teraplikasi memlalui kemampuan serta kesungguhan memberikan pelayanan kepada masyarakat dan memberikan pelayanan kepada pimpinan serta rekan kerja. Kinerja bawahan di Satuan Sabhara Polres Batu pada segi indikator integritas teraplikasi melalui kemampuan bertindak sesuai dengan nilai, norma serta etika dalam menyelesaikan tugas pekerjaan serta bertindak dalam menyelesaikan tugas pekerjaan sesuai dengan Standar Operasional serta Prosedur.

Organisasi kepolisian mempuyai SOP atau Tupoksi yang berfungsi untuk mengatur anggota, hal ini merupakan pedoman bagi anggota dalam melaksanakan tugas. Seluruh anggota polisi di harus kan mengikuti peraturan sesuai dengan undang-undang kepolisian karena dasar dari ketentuan berasal dari undang-undang peraturan yang resmi di buat oleh pimpinan. Dalam satuan sabhara anggota melaksanakan tugas yang diberikan sesuai dengan tupoksi yang berlaku, anggota yang patuh dengan ketentuan akan dapat menyesuaikan diri dengan tekanan kerja, tugas-tugas dinas lapangan maupun intruksiintruksi dari atasan. Anggota yang taat pada peraturan akan terhindar dari kesalahan atau pelanggaran, maka tidak akan sanksi atau hukuman yang diterima oleh anggota yang bersangkutan. Karena begitu penting nya ketentuan serta peraturan sehingga menuntut agar anggota nya memiliki disiplin pada tiap kegiatan sehari-harinya di kantor maupun dilingkungan kerja bersama rekan anggota lainnya.

Melalui pembinaan dan pemberdayaan pimpinan maka Satuan Sabhara Polres Batu akan lebih memahami dan mengikuti Standar operasional Prosedur (SOP) berdasarkan pada Rencana Kerja Polresta tahun 2014 dengan berpedoman pada Juklak, Juklak dan Juknis Kepolisian serta kebijaksanaan pimpinan Polresta. Organisasi memiliki standar operasional prosedur sesuai dengan tingkatan kerja atau tugas yang berbeda beda didalam prosedur terdapat tingkatan pelaksanaan tugas dan realisasi tugas. Tidak bisa dipungkiri bahwa keberadaan prosedur sangat penting untuk menyelesaikan tugas dari lokasi umum maunpun lokasi yang khusus. Standar opersional prosedur wajib untuk di ketahui oleh setipa individu yang bergabung dalam organisasi dengan tujuan yang sama karena didalamnya juga terdapat rancangan-rancangan kedepan. Kaidah kerja kantor yang tidak bisa dilepas kan untuk anggota seperti melayani masyarakat dengan tulus dan ikhlas selalu 
menerima aduan atau pun keluhan masalah masyarakat, etika anggota juga dalam bekerja maupun bertugas tidak lepas dari pedoman prosedur. Jika anggota mengikuti prosedur maka muncullah kesimbangan tugas. Prosedur yang memiliki rumusan ketetapan yang jelas agar mudah dimengerti oleh anggota, aturan ketentuan masuk akal maksud nya harus sesuai dengan kondisi dan situasi pada organisasi, dan prosedur dijalankan secara bertahap tanpa melangkau tahap-tahap yang sudah ditentukan. Standar operasional prosedur menjadi salah satu syarat untuk terbentuk nya organisasi resmi karena untuk melakukan tugas di perlukan aturan ketentuan prosedur untuk menunjang pencapaian. Dalam standar operasional prosedur kepolisian harus didasari oleh undang-undang tentang Kepolisian Republik Indonesia dan didasari pula dengan Skep Kapolri.

Pimpinan mewajibkan pada anggota untuk melaksanakan tugas dengan tahaptahap yang ada dimulai dari tahap awal persiapan, tahap pelaksanaan sampai pada tahan akhir yaitu pelaporan. Kepatuhan pada prosedur diharapkan akan membawa pada lancarnya segala dinas lapangan anggota maupun pada kerja yang ada di kantor. Ketentuan prosedur tidak bisa diganggu gugat karena sudah dari atasan dengan jabatan yang lebih tinggi dari seorang kasat yang menetukan ketetapan standar operasional prosedur. Selain aturan langsung dari atasan, standar operasional prosedur merupakan peraturan berbentuk tertulis yang harus dan wajib anggota ketahui dan pahami. Ketententuan-ketentuan yang mengarahkan cara bekerja maupun bertugas para anggota secara terstruktur.

Anggota tidak boleh melepaskan prosedur yang berlaku, anggota harus memegang prosedur dan menjadikannya sebagi pedoman untuk bertugas. Agar tugas yang dilakukan lebbih terarah dan tidak melenceng dari ketententuan yang sudah di sepakati kaidah kerja di kantor seperti saling tegur sapa dengan senyuman baik itu dari atasan untuk anggota maupun dari anggota dengan rekan anggota lainnya, hal ini akan menumbuhkan rasa kekompakan antara sesama sehingga lebih akrab dan solid menumbuhkan kecocokan pada bagian unit pelaksanaan tugas. Pengecekan secara berkala yang dilakukan anggota untuk memastikan apakah tugas benar-benar selesai. Menunjukan kemampuan dalam mengatasi masalah yang tiba-tiba muncul dapat dengan teliti memilah pekerjaan maupun tugas dan memecahkan masalahnya dengan hati-hati. 


\section{KESIMPULAN DAN SARAN}

\section{Kesimpulan}

Pembinaan dan pemberdayaan pimpinan sangat berpengaruh terhadap kinerjabawahan di satuan Sabhara Polres Batu hal ini terlihat Pelaksanaan tugas Satuan Sabhara Polresta Batu sebagian besar telah terlaksana dengan baik, dan telah berupaya meningkatkan pelaksanaan tugas fungsi Sabhara yang berwibawa di tengah-tengah masyarakat untuk menciptakan situasi kamtibmas yang mantap dan terkendali dikarenakan adanya program pembinaan dan pemberdayaan pimpinan dilaksanakan secara baik, rutin dan terus menerus.

\section{Saran}

a. Dalam rangka meningkatkan kemampuan teknis Kepolisian, di usulkan kepada pimpinan terhadap anggota untuk dapat mengikuti pendidikan pembentukan dan kejuruan dasar / lanjutan bidang Sabhara maupun bidang-bidang yang lainnya

b. Dalam mengatasi gangguan kamtibmas yang terjadi di wilayah Polresta Batu perlunya pemberdayaan kinerja kerja semaksimal mungkin kepada anggota dengan tugas operasional dengan mengutamakan disiplin anggota dan tidak terlepas dari perwujudan citra dan wibawa Polri di tengah-tengah masyarakat melalui kebijaksanaan Kapolri.

\section{REFERENSI}

Anggreny, D. E. 2018. Analisis Faktor Yang Berhubungan Dengan Kinerja Petugas Kesehatan Pada Program Tb Paru. Jurnal'Aisyiyah Medika, 2(1).

Ardiana, I., Brahmayanti, I. A., \& Subaedi, S. 2010. Kompetensi SDM UKM dan pengaruhnya terhadap kinerja UKM di Surabaya. Jurnal Manajemen Dan Kewirausahaan, 12(1), pp-42.

Gunawan, I. 2013. Metode Penelitian Kualitatif. Jakarta: Bumi Aksara, 143.

Hadi, A. P. 2010. Konsep pemberdayaan, partisipasi dan kelembagaan dalam pembangunan. Yayasan Agribisnis/Pusat Pengembangan Masyarakat Agrikarya (PPMA). 
Hendayady, A. 2011. PEMBERDAYAAN APARATUR DAERAH. Jurnal Ilmu Politik Dan Ilmu Pemerintahan, 1(1), 61.

Kusumawati, N., \& Maruti, E. S. 2019. Strategi belajar mengajar di sekolah dasar. CV. AE MEDIA GRAFIKA.

Machmud, M. 2014. Analisis Kinerja Keuangan Daerah Di Provinsi Sulawesi Utara Tahun 2007-2012. Jurnal Berkala Ilmiah Efisiensi, 14(2).

Nurohman, A. (n.d.). Perpustakaan Sebagai Teropong Profesionalisme Pustakawan.

Putri, H. R. 2016. Pengaruh pendidikan, pengalaman kerja, dan jenis kelamin terhadap produktivitas kerja karyawan bagian produksi CV. Karunia Abadi Wonosobo. Jurnal Pendidikan Dan Ekonomi, 5(4), 292-300.

Rosita, T., \& Yuniati, T. 2016. Pengaruh kepuasan kerja terhadap kinerja karyawan dengan komitmen organisasional sebagai variabel intervening. Jurnal Ilmu Dan Riset Manajemen (JIRM), 5(1).

Savitri, R. 2018. Pemenuhan Hak Anak Untuk Tidak Dipublikasikan Identitasnya Dalam Proses Peradilan Pidana Anak (Studi Di Polrestabes Semarang). Unika Soegijapranata Semarang.

Semiawan, C. R. 2010. Metode penelitian kualitatif. Grasindo.

Siswahyudi, A. 2018. Kebijakan Pemberian Tambahan Perbaikan Penghasilan Pemerintah Kabupaten Kediri. Mediasosian, Vol. 2(2), hal. 10-14.

Soendari, T. 2012. Metode Penelitian Deskriptif. Bandung, UPI. Stuss, Magdalena \& Herdan, Agnieszka, 17.

Sudiyatno, B., \& Puspitasari, E. 2010. Tobin's q dan altman z-score sebagai indikator pengukuran kinerja perusahaan. Kajian Akuntansi, 2(1).

Sugiono, S. 2016. Metode Penelitian Kuantitatif, Kualitatif, dan $R \&$ D. Bandung: Alfabeta.

Thoha, M. 2017. Ilmu administrasi publik kontemporer. Kencana. 